\title{
Diarrheal morbidity and predisposing factors among children under 5 years of age in rural East Ethiopia
}

\author{
Ephrem Tefera Solomon ${ }^{1,2^{*}}$ (D), Sirak Robele Gari ${ }^{1}$, Helmut Kloos ${ }^{3}$ and Bezatu Mengistie ${ }^{2}$
}

\begin{abstract}
Background: Diarrheal diseases remain a leading cause of preventable death among children under-five in lowand middle-income countries (LMICS). In Ethiopia, diarrhea is the major contributor to deaths for children under the age of 5 years. In order to develop prevention strategies for the alleviation of childhood diarrhea, it is necessary to identify the important predisposing factors. These predisposing factors have been observed to vary by location across Eastern Ethiopia. Moreover, the evidence on prevalence and determinants of diarrhea among children under 5 years of age in Dire Dawa and its suburbs is very limited and those available have been erratic. The objective of this study was to determine the prevalence and predisposing factors of diarrhea among children under the age of 5 years in rural Dire Dawa, East Ethiopia.
\end{abstract}

Methods: A community-based cross-sectional study was conducted in rural Dire Dawa City Administration in May 2018. Multistage sampling technique was employed to recruit 1180 under-five children from the rural population of Dire Dawa City Administration. Data on socio-demographic, environmental, and child- and hygiene-related factors were collected by trained data collectors using a structured questionnaire. Logistic regression was used to identify independent risk factors for childhood diarrhea.

Results: The 2-week prevalence of diarrhea among the under-five children was $23 \%$ (95\% Cl 20.8-25.7\%). Maternal diarrhea ( $A O R=2.22,95 \% \mathrm{Cl} 1.10-4.47$ ), handwashing after contact with child feces ( $\mathrm{AOR}=6.27,95 \% \mathrm{Cl} 2.01-$ 19.55), use of a dipper to draw water from containers ( $A O R=2.88,95 \% \mathrm{Cl} 1.41-5.89$ ), and presence of a refuse disposal facility ( $A O R=2.47,95 \% \mathrm{Cl} 1.09-5.60)$ were the significant predisposing factors of diarrhea.

Conclusion: Our study identified a high burden of childhood diarrheal disease in rural Dire Dawa City Administration in Eastern Ethiopia. The identified risk factors were maternal diarrhea, handwashing after contact with child feces, use of a dipper to draw water from containers, and presence of refuse disposal facility. To minimize the risk of diarrhea, health education programs focusing on good hygiene practice and sanitation as well as early treatment are recommended.

Keywords: Diarrheal morbidity, Predisposing factors, Children under 5 years of age, Handwashing, Dire Dawa

\footnotetext{
* Correspondence: ephtesol@gmail.com

${ }^{1}$ Ethiopian Institute of Water Resources, Addis Ababa University, Addis Ababa, Ethiopia

${ }^{2}$ College of Health and Medical Sciences, Haramaya University, Harar, Ethiopia Full list of author information is available at the end of the article
}

(c) The Author(s). 2020 Open Access This article is licensed under a Creative Commons Attribution 4.0 International License, which permits use, sharing, adaptation, distribution and reproduction in any medium or format, as long as you give appropriate credit to the original author(s) and the source, provide a link to the Creative Commons licence, and indicate if changes were made. The images or other third party material in this article are included in the article's Creative Commons licence, unless indicated otherwise in a credit line to the material. If material is not included in the article's Creative Commons licence and your intended use is not permitted by statutory regulation or exceeds the permitted use, you will need to obtain permission directly from the copyright holder. To view a copy of this licence, visit http://creativecommons.org/licenses/by/4.0/. 


\section{Introduction}

Diarrheal diseases remain a leading cause of preventable death, especially among children under-five in LMICs [1]. Globally, an estimated 2 billion cases of diarrhea occur each year, and 1.9 million children under the age of 5 years, mostly in LMICs, die from diarrhea [2]. It is defined as the passage of three or more loose or liquid stools per day [3]. Several studies identified the following risk factors for under-five diarrhea: mother's/guardian's age, education, and occupation $[4,5]$. Similar studies detected predisposing factors such as maternal history of recent diarrhea, lack of latrines, age of the child [6], and absence of refuse disposal facilities [7] in Ethiopia. However, some practices such as use of treated water, handwashing before feeding under-five child, and use of narrow-mouth container for storage of drinking water have been noted to significantly lower the risk of childhood diarrhea $[8,9]$.

In Ethiopia, diarrhea is the major contributor to the deaths for children under the age of 5 years [10]. According to the 2016 Ethiopia Demographic and Health Survey, the prevalence of under-five diarrhea was $12.1 \%$ and $12 \%$ in Ethiopia and Dire Dawa, Eastern Ethiopia, respectively [11]. According to the 2017 Dire Dawa City Administration Regional Health Bureau's Annual Report, the prevalence of under-five diarrhea in the administration was 35.5\% (Dire Dawa City Administration Regional Health Bureau: 2017 Facility Information (unpublished observation)). Studies carried out in different localities of Ethiopia revealed high burden of diarrheal morbidity. For instance, 2-week period prevalence was $22.1 \%$ in rural areas of North Gondar Zone; $28.9 \%$ in Nekemte Town in western Ethiopia; 27.3\% in Jigjiga District, Somali Region; and 22.5\% in Kersa District both in Eastern Ethiopia [7, 12-14].

Despite the high prevalence of childhood diarrhea in Ethiopia, there is clear variation in the epidemiological reports from different localities. Moreover, there is little information on the prevalence and determinants of diarrhea among children under 5 years of age in Dire Dawa and its suburbs, and existing results are inconsistent. For instance, a systematic review and meta-analysis revealed that the prevalence of under-five diarrhea in Dire Dawa was 26\% [15] and in rural kebeles of Dire Dawa it was $37.1 \%$ [16]. Children using water from unprotected springs or wells were more likely to be infected with diarrhea-causing bacteria [17]. The objective of this study is to determine the prevalence and predisposing socio-demographic, behavioral, and environmental factors of diarrhea among children under the age of 5 years in rural districts of Dire Dawa, East Ethiopia.

\section{Methods}

\section{Study design and area}

A community-based cross-sectional study was conducted in rural Dire Dawa City Administration in May
2018. Dire Dawa is the second largest city in Ethiopia located about 505 kilometers to the east of Addis Ababa (Dire Dawa Administration Statistical Abstract 2013/142014/15; Prepared by Dire Dawa Administration Bureau of Finance and Economic Development [unpublished]). The City administration has nine urban and 38 rural kebeles (neighborhood associations). There are two government hospitals, five private hospitals, 15 health centers, and 33 health posts (Dire Dawa administration Regional Health Bureau: 2017 six months report [unpublished]). According to the 2007 National Census Report, the total population of Dire Dawa City Administration was 341,834 , of which just over half $(50.2 \%)$ were males and $31.8 \%$ lived in rural areas (Dire Dawa Administration Statistical Abstract 2013/14-2014/15; prepared by Dire Dawa Administration Bureau of Finance and Economic Development [unpublished]). According to the Regional Health Bureau Report of 2017, there were 34, 150 households in the four districts of rural Dire Dawa with 20,118 children under the age of 5 years (Dire Dawa Administration Regional Health Bureau: 2017 Facility Information and Document review from Dire Dawa Administration Disaster Risk Management Bureau [Unpublished]).

\section{Inclusion and exclusion criteria}

Households having one child aged between 6 and 59 months were included. All, under-five children with persistent diarrhea and caretakers or household heads who were severely ill and unable to respond to the questionnaire were excluded.

\section{Population and sampling}

All households with at least one under-five child in the 38 rural kebeles (a kebele is the smallest administrative unit of Ethiopia, similar to a ward, a neighborhood) of the four districts were the source population whereas the under-five children in the randomly selected four kebeles were the study populations. The sample size was calculated using the formula for estimation of a single population proportion [18], $n=z_{1-\alpha / 2}^{2} P(1-P) / d^{2}$, where $z_{1-\alpha / 2}$ is $1.96 ; P$ is prevalence of diarrhea among children under 5 years of age in Eastern Ethiopia, Kersa District, estimated to be $22.5 \%$ [14]; $d$ is acceptable margin of error is $5 \%(0.05)$, and the level of confidence is $95 \%$. The calculated sample size was 268. After considering a design effect of four accounting for two stage sampling [19] and 10\% compensation for expected non-response, the sample size became 1180. In this study, four of 38 kebeles were selected using simple random sampling, and the participating households were also selected using simple random sampling from a sampling frame known as "family folders" in the health centers and health posts. Accordingly, a design effect of 
four is introduced as an adjustment for the multi-stage sampling employed.

A multi-stage sampling procedure was used to recruit the calculated sample size from the rural population of Dire Dawa City Administration. Four of the 38 rural kebeles were selected using a simple random sampling technique. The kebeles in the four districts were listed and written on pieces of papers; then, four kebeles were randomly selected using a draw method. Those eligible for this study were households having at least one under-five child. Then, the study households were selected again using a simple random sampling technique from the "family folders" that were regularly updated by the respective health centers and health posts. In households with more than one under-five child, the index under-five child was selected by using the lottery method.

\section{Data collection}

All data were collected using a structured questionnaire that was administered to the study participants by trained data collectors. The questionnaire was first prepared in English and then translated into the local language (Afaan Oromo). It was then back translated to English by an anonymous translator to ensure the consistency of the two versions. Sixteen data collectors and four supervisors were employed. The data collectors were local residents of the respective kebeles who completed grade 10 and who spoke the local language, and the supervisors were also local residents who completed grade 12. All data collectors and supervisors received two days of training on interviewing techniques and data collection from the first author. Information on diarrhea for the included study participant in the household in the 2 weeks prior to the interviews and information related to diarrhea was collected from the mother or guardian of each under-five child.

\section{Study variables \\ Dependent variable}

Childhood diarrhea in the 2 weeks preceding the survey was the dependent variable.

\section{Independent variables}

Child age [5] and sex [20], mother's age and education [4], mothers occupation [5], father's education [21], number of under-five children [22], quality of the main floor material [5], drinking water source [23], maternal diarrhea [6], storing water in containers without lids [20], use of dippers to draw water from water storage containers [9], availability of a latrine [23], method of under-five child stool disposal [23], improper refuse disposal [24], availability of handwashing (handwashing is defined as the act of cleaning one's hands to remove soil, grease, microorganisms, or other unwanted substances) facility [14], handwashing before preparing food and before eating food [8], before feeding a child [13], handwashing after eating and after contact with child feces [13], visible feces in the compound [7], and visible feces on the latrine slab [7] were the independent variables.

\section{Data quality assurance}

Adequate training was given to data collectors and supervisors on techniques of interviewing and general approaches to community motivation and supervision. The data collection tool was pretested in a nearby kebele that was not included in the study in order to distinguish language barriers and contextual differences. Questionnaires were checked daily for their consistencies and completeness by the supervisors. The questionnaires were checked for uniformity of units of measurement used as well as for missing data that were obtained the next day by data collectors. Supervisors also checked the accuracy of data by randomly interviewing some of the participating households. At the end of data collection, the principal investigator verified proper data collection each day by holding a short meeting with the supervisors.

\section{Data analysis}

The collected data were cleaned and entered onto EPIData Version 3.1 and analyzed using analysis format, SPSS for Windows Version 23. Descriptive statistics such as percentages, means, standard deviations, and proportions of the study variables were carried out. Explanatory variables were tested for multi-collinearity using the variance inflation factor (VIF) and the tolerance test.

The explanatory variables were classified into three major categories: socio-demographic, environmental, and child- and hygiene-related factors. Bivariate analysis was used to examine the association between each of the three explanatory variables and the outcome variable, diarrhea. Then, multivariable logistic regression was used to identify independent risk factors of childhood diarrhea after incorporating explanatory variables scoring a $p$ value of less than 0.1 in bivariate regression; despite the limitations of the logistic regression such as the assumption of linearity between the dependent variable and the independent variables, in the real world, the data is rarely linearly separable. If the number of observations are less than the number of features, logistic regression should not be used; otherwise, it may lead to overfit and logistic regression can only be used to predict discrete functions. $P$ values less than 0.05 were considered significant in the multivariable regression. 


\section{Results}

A total of 1146 households included in this study with a response rate of $97.1 \%$. Out of the 1146 under-five children, 576 (50.3\%) were males. More than three-quarters, $77.8 \%$, were from the Oromo ethnic group and $22.2 \%$ were Somali. Socio-demographic characteristics of the parents of the children are shown in Table 1 . The 2 week prevalence of diarrhea in rural Dire Dawa among the under-five children was 23\% (95\% CI 20.8-25.7\%).

\section{Socio-demographic factors}

The majority of the mothers/guardians had no formal education ((crude odds ratio) OR $=3.19$, 95\% CI 1.26$8.10)$, were single $(\mathrm{OR}=1.10,95 \% \mathrm{CI} 0.60-1.99)$, and were housewives $(\mathrm{OR}=0.97,95 \% \mathrm{CI} 0.71-1.32)$. Nearly half of the households had a single room $(\mathrm{OR}=1.58,95 \% \mathrm{CI}$ 1.20-2.09). Mothers'/guardians' educational status and number of living rooms had a statistically significant effect on under-five diarrhea. Socio-demographic factors of diarrhea are indicated in Table 2.

\section{Child- and hygiene-related factors}

Analysis of child- and hygiene-related factors showed that most of the under-five children practiced open defecation $(\mathrm{OR}=1.42,95 \% \mathrm{CI} 1.06-1.89)$ and some of the mothers or guardians had diarrhea 2 weeks before the interview $(\mathrm{OR}=3.83,95 \% \mathrm{CI} 2.88-5.14)$. Few mothers/guardians washed their hands with soap before eating food $(\mathrm{OR}=1.74,95 \% \mathrm{CI} 1.03-2.93)$, and most of the mothers/guardians did not wash their hands with soap after cleaning children's bottom $(\mathrm{OR}=1.83,95 \%$ CI 1.19-2.80). Open defecation, maternal diarrhea, and mother's/guardian's handwashing habit before eating and after cleaning children's bottom were significantly associated with childhood diarrhea (Table 3).

\section{Environmental factors}

Analysis of environmental factors showed that some households had flowing water daily for $1 \mathrm{~h}$ or less $(\mathrm{OR}=$ $2.54,95 \%$ CI 1.78-3.63). The majority of the households had a refuse disposal facility $(\mathrm{OR}=3.19,95 \%$ CI $2.16-$ 4.72) and disposed of the stools of under-five children in

Table 1 Socio-demographic characteristics of the parents of the under-five children, rural areas of Dire Dawa City Administration, 2018

\begin{tabular}{|c|c|c|c|c|}
\hline \multicolumn{3}{|l|}{ Variables } & \multirow{2}{*}{$\begin{array}{l}\text { Frequencies } \\
926\end{array}$} & \multirow{2}{*}{$\begin{array}{l}\text { Percentage } \\
80.8\end{array}$} \\
\hline Mothers'/guardians' & Ethnicity & Oromo & & \\
\hline & & Somali & 220 & 19.2 \\
\hline & Religion & Muslim & 1141 & 99.6 \\
\hline & & Orthodox Christian & 4 & 0.3 \\
\hline & & Protestant & 1 & 0.1 \\
\hline & Educational status & No formal education & 789 & 68.8 \\
\hline & & Primary education & 298 & 26.0 \\
\hline & & Secondary education & 44 & 3.8 \\
\hline & & Above secondary education & 15 & 1.3 \\
\hline & Occupation & Housewife & 843 & 73.6 \\
\hline & & Farmer & 261 & 22.8 \\
\hline & & Merchant & 21 & 1.8 \\
\hline & & Day laborer & 3 & 0.3 \\
\hline & & Government employee & 18 & 1.6 \\
\hline \multirow[t]{12}{*}{ Fathers' } & Ethnicity & Oromo & 841 & 73.4 \\
\hline & & Somali & 244 & 21.3 \\
\hline & Religion & Muslim & 1084 & 94.6 \\
\hline & & Orthodox Christian & 1 & 0.1 \\
\hline & Educational status & No formal education & 576 & 50.3 \\
\hline & & Primary education & 371 & 32.4 \\
\hline & & Secondary education & 88 & 7.7 \\
\hline & & Above secondary education & 50 & 4.4 \\
\hline & Occupation & Farmer & 961 & 83.9 \\
\hline & & Merchant & 20 & 1.7 \\
\hline & & Day laborer & 16 & 1.4 \\
\hline & & Government employee & 88 & 7.7 \\
\hline
\end{tabular}


Table 2 Distribution of diarrheal disease in relation to sociodemographic factors, rural Dire Dawa, Eastern Ethiopia, 2018

\begin{tabular}{lll}
\hline Factors & Diarrhea $(\boldsymbol{n}=1146)$ & $\begin{array}{l}\text { Crude OR } \\
\left(95 \% \mathrm{Cl}^{\mathrm{b}}\right.\end{array}$ \\
\cline { 2 - 3 } & Yes $\quad$ No & \\
\hline
\end{tabular}

\begin{tabular}{llll}
\hline Age of the mother/guardian (years) & & \\
$18-24$ & 38 & 111 & $1.14(0.71-1.84)$ \\
$25-34$ & 172 & 591 & $0.97(0.69-1.37)$ \\
$\geq 35$ & 54 & 180 & 1
\end{tabular}

Education of mother/guardian

$\begin{array}{llll}\text { No formal education } & 180 & 609 & 3.19(1.26-8.10) \\ \text { Primary education } & 79 & 219 & 3.90(1.50-10.09) \\ \text { Secondary and above } & 5 & 54 & 1\end{array}$

Occupation of the mother/guardian

$\begin{array}{llll}\text { Housewife } & 193 & 650 & 0.97(0.71-1.32) \\ \text { Miscellaneous } & 71 & 232 & 1\end{array}$

Age of the father (years)

$\begin{array}{llll}20-39 & 188 & 630 & 1.01(0.73-1.40) \\ \geq 40 & 61 & 206 & 1\end{array}$

Education of the father

$\begin{array}{llll}\text { No formal education } & 143 & 433 & 1.26(0.94-1.67) \\ \begin{array}{l}\text { Primary and above } \\ \text { Family size }\end{array} & 106 & 403 & 1 \\ \quad \begin{array}{l}\text { Five or less } \\ \text { Six or above }\end{array} & 182 & 592 & 1 \\ \text { Living with spouse } & 82 & 290 & 0.92(0.68-1.24) \\ \text { Yes } & 249 & 836 & 1 \\ \text { No } & 15 & 46 & 1.10(0.60-1.99)\end{array}$

Number of living rooms

\begin{tabular}{llll} 
One & 152 & 407 & $1.58(1.20-2.09)$ \\
Two and above & 112 & 475 & 1 \\
\hline
\end{tabular}

${ }^{\text {aOdds ratio }}$

b95\% confidence interval

and around the compound ( $\mathrm{OR}=1.91,95 \%$ CI $1.35-$ $2.71)$. The length of daily supply of water from the public tap, use of a dipper to draw water from containers, presence of a refuse disposal facility, stool disposing method for under-five children, presence of feces, and refuse in and around the house were significantly associated with childhood diarrhea (Table 4).

\section{Predisposing factors of diarrhea among under-five children}

In the final multivariable regression, four models were tested to identify the predisposing factors for childhood diarrhea. In the fourth model, four predisposing factors were independently associated with childhood diarrhea. They are maternal diarrhea (AOR (adjusted odds ratio) $=2.22$, 95\% CI 1.10-4.47), handwashing after contact with child feces $(\mathrm{AOR}=6.27,95 \%$ CI 2.01-19.55), use of
Table 3 Diarrheal disease in relation to child- and hygienerelated factors, rural Dire Dawa, Eastern Ethiopia, 2018

\begin{tabular}{|c|c|c|c|}
\hline \multirow[t]{2}{*}{ Factors } & \multicolumn{2}{|c|}{ Diarrhea $(\boldsymbol{n}=1146)$} & \multirow{2}{*}{$\begin{array}{l}\text { Crude OR (95\% } \\
\text { Cl) }\end{array}$} \\
\hline & Yes & No & \\
\hline \multicolumn{4}{|l|}{ Gender } \\
\hline Male & 128 & 448 & 1 \\
\hline Female & 136 & 434 & $1.10(0.83-1.44)$ \\
\hline \multicolumn{4}{|l|}{ Age } \\
\hline $6-11$ & 19 & 62 & $1.01(0.59-1.74)$ \\
\hline $12-23$ & 51 & 179 & $0.94(0.66-1.34)$ \\
\hline$>23$ & 194 & 641 & 1 \\
\hline
\end{tabular}

Number of under-five children in the household

$\begin{array}{llll}\text { One } & 123 & 445 & 1 \\ \text { Two and above } & 141 & 537 & 1.17(0.89-1.54)\end{array}$

Open defecation by the under-five child

$\begin{array}{llll}\text { No } & 90 & 373 & 1 \\ \text { Yes } & 174 & 509 & 1.42(1.06-1.89) \\ \text { Maternal diarrhea } & & & \\ \text { No } & 128 & 691 & 1 \\ \text { Yes } & 136 & 191 & 3.83(2.88-5.14)\end{array}$

Availability of handwashing facility

$\begin{array}{llll}\text { No } & 204 & 661 & 1.14(0.82-1.57) \\ \text { Yes } & 60 & 221 & 1\end{array}$

Mother washing hands before preparing food

$\begin{array}{llll}\text { No } & 184 & 667 & 1.23(0.77-1.97) \\ \text { Yes } & 24 & 107 & 1\end{array}$

Mother washing hands before eating food

$\begin{array}{llll}\text { No } & 194 & 683 & 1.74(1.03-2.93) \\ \text { Yes } & 18 & 110 & 1\end{array}$

Mother washing hands before feeding child

$\begin{array}{llll}\text { No } & 178 & 644 & 1.19(0.79-1.77) \\ \text { Yes } & 35 & 150 & 1\end{array}$

Mother washing hands after defecation

$\begin{array}{llll}\text { No } & 175 & 631 & 1.12(0.76-1.67) \\ \text { Yes } & 37 & 150 & 1\end{array}$

Handwashing after washing child's bottom

\begin{tabular}{llll} 
No & 177 & 592 & $1.83(1.19-2.80)$ \\
Yes & 29 & 177 & 1 \\
\hline
\end{tabular}

a dipper to draw water from a container $(\mathrm{AOR}=2.88$, 95\% CI 1.41-5.89), and presence of refuse disposal facility (AOR $=2.47,95 \%$ CI 1.09-5.60).

The odds of diarrhea in children of mothers/guardians who had had diarrhea were 2.22 times higher than children from mothers/ guardians who had had not diarrhea. Children from mothers/guardians who had not washed their hands with soap after contact with child feces had 6.27 times higher odds of diarrhea than their 
Table 4 Distribution of diarrheal disease in relation to environmental factors, rural Dire Dawa, Eastern Ethiopia, 2018

\begin{tabular}{|c|c|c|c|}
\hline \multirow[t]{2}{*}{ Factors } & \multicolumn{2}{|c|}{ Diarrhea $(\boldsymbol{n}=1146)$} & \multirow{2}{*}{$\begin{array}{l}\text { Crude OR (95\% } \\
\mathrm{Cl})\end{array}$} \\
\hline & Yes & No & \\
\hline \multicolumn{4}{|l|}{ Source of drinking water } \\
\hline Improved & 189 & 662 & 1 \\
\hline Unimproved & 75 & 220 & $1.19(0.88-1.63)$ \\
\hline \multicolumn{4}{|l|}{ Daily availability water supply from the public tap } \\
\hline$\leq 1 \mathrm{~h}$ & 69 & 122 & $2.54(1.78-3.63)$ \\
\hline$\geq 2 \mathrm{~h}$ & 120 & 540 & 1 \\
\hline \multicolumn{4}{|l|}{ Use of dipper to draw water from container } \\
\hline No & 53 & 476 & 1 \\
\hline Yes & 211 & 406 & $4.67(3.36-6.49)$ \\
\hline \multicolumn{4}{|l|}{ Latrine present } \\
\hline No & 168 & 522 & $1.21(0.91-1.60)$ \\
\hline Yes & 96 & 360 & 1 \\
\hline \multicolumn{4}{|l|}{ Presence of refuse disposal facility } \\
\hline No & 231 & 606 & $3.19(2.16-4.72)$ \\
\hline Yes & 33 & 276 & 1 \\
\hline \multicolumn{4}{|l|}{ Under-five children stool disposing method } \\
\hline Burying and disposing out of the compound & 97 & 385 & 1 \\
\hline Disposing in and around the compound & 78 & 162 & $1.91(1.35-2.71)$ \\
\hline \multicolumn{4}{|l|}{ Feces in and around the house } \\
\hline No & 139 & 582 & 1 \\
\hline Yes & 125 & 300 & $1.75(1.32-2.31)$ \\
\hline \multicolumn{4}{|l|}{ Refuse in and around the house } \\
\hline No & 133 & 542 & 1 \\
\hline Yes & 131 & 340 & $1.57(1.20-2.10)$ \\
\hline
\end{tabular}

counter parts. Similarly, children from households using a dipper to draw water had 2.88 higher odds of diarrhea than children from households not using a dipper. Likewise, children in households without a refuse disposal facility had 2.47-folds of acquiring diarrhea than children in households with a refuse disposal facility (Table 5).

\section{Discussion}

In this study, we explored the socio-demographic, environmental, and child- and hygiene-related predisposing factors of diarrhea in children younger than 5 years of age in rural areas of Dire Dawa City Administration. Recent history of maternal diarrhea, absence of handwashing after contact with child feces, use of a dipper for drawing water from the container, and non-availability of refuse disposal facilities were the significant predisposing factors of under-five diarrhea.

The 2-week prevalence of under-five diarrhea was $23 \%$ (95\% CI 20.8\%, 25.7\%). Similar rates were reported by other studies in Ethiopia; for example, $22.1 \%$ in North Gondar Zone [12], 22.1\% in Benishangul Gumuz Region
[22], 27.3\% in Jigjiga District [13], and 22.5\% in Kersa District [14]. Similar studies in other African countries revealed comparable results. For example, in Egypt, diarrhea prevalence was 23.6\% [21], in Cameroon 23.8\% [9], and in Ghana 19.2\% [25]. However, the rate was markedly higher than those reported by studies in Farta Wereda in northwest Ethiopia (16.9\%) [26], Mecha District in West Gojam Zone (18\%) [6], and at the national level (12.0\%) [11]. But, were lower than those studies conducted in the country, Nekemte Town in western Ethiopia (28.9\%) [7] and Arba-Minch District in southern Ethiopia (30.5\%) [27]. These differences may be due to variations in socio-economic, behavioral, and environmental factors.

Mothers'/guardians' diarrhea is one of the risk factors of diarrhea in under-five children. In our study, after adjusting for all predictors of childhood diarrhea, underfive children from mothers/guardians who had diarrhea recently were two times more likely to develop diarrheal disease than under-five child from mothers/guardians who did not have diarrhea recently (adjusted OR $=2.22$ 
Table 5 Multivariable regression predicting the probability of diarrhea among under-fives, rural Dire Dawa, Eastern Ethiopia, 2018

\begin{tabular}{|c|c|c|c|c|}
\hline Predisposing factors & Model I, AOR* $(95 \% \mathrm{Cl})$ & Model II, AOR (95\% Cl) & Model III, AOR (95\% Cl) & Model IV, AOR (95\% Cl) \\
\hline \multicolumn{5}{|l|}{ Educational status of mother/guardian } \\
\hline No formal education & $2.89(1.13-7.35)^{* *}$ & & & $2.92(0.28-30.10)$ \\
\hline Primary education & $3.76(1.49-9.76)^{* *}$ & & & $3.42(0.33-35.84)$ \\
\hline Secondary and above & 1 & & & 1 \\
\hline \multicolumn{5}{|l|}{ Number of living rooms } \\
\hline Single room & $1.59(1.20-2.10)^{* *}$ & & & $0.84(0.45-1.57)$ \\
\hline Two or above & 1 & & & 1 \\
\hline \multicolumn{5}{|l|}{ Open defecation practice by the U5 child } \\
\hline No & & 1 & & 1 \\
\hline Yes & & $1.52(1.07-2.15)^{* *}$ & & $1.30(0.65-2.63)$ \\
\hline \multicolumn{5}{|l|}{ Maternal diarrhea } \\
\hline No & & 1 & & 1 \\
\hline Yes & & $3.30(2.33-4.66)^{* *}$ & & $2.22(1.10-4.47)^{* *}$ \\
\hline \multicolumn{5}{|l|}{ Mother's handwashing before eating food } \\
\hline No & & $1.22(0.64-2.34)$ & & $0.77(0.23-2.64)$ \\
\hline Yes & & 1 & & 1 \\
\hline \multicolumn{5}{|l|}{ Handwashing after contact with child feces } \\
\hline No & & $1.69(1.03-2.77)^{* *}$ & & $6.27(2.01-19.55)^{* *}$ \\
\hline Yes & & 1 & & 1 \\
\hline \multicolumn{5}{|l|}{ Stay time of water supply from the public tap } \\
\hline$\leq 1 \mathrm{~h}$ & & & $1.83(1.09-3.06)^{* *}$ & $1.14(0.47-2.77)$ \\
\hline$\geq 2 h$ & & & 1 & 1 \\
\hline \multicolumn{5}{|l|}{ Use of dipper to draw water from container } \\
\hline No & & & 1 & 1 \\
\hline Yes & & & $3.01(1.73-5.23)^{* *}$ & $2.88(1.41-5.89)^{* *}$ \\
\hline \multicolumn{5}{|l|}{ Presence of refuse disposal facility } \\
\hline No & & & $3.31(1.69-6.51)^{* *}$ & $2.47(1.09-5.60)^{* *}$ \\
\hline Yes & & & 1 & 1 \\
\hline \multicolumn{5}{|l|}{ Under-five children stool disposing method } \\
\hline Burying and disposing outside the compound & & & 1 & 1 \\
\hline Disposing in and around the compound & & & $1.86(1.16-2.99)^{* *}$ & $0.83(0.40-1.73)$ \\
\hline \multicolumn{5}{|l|}{ Presence of feces in or around the house } \\
\hline No & & & 1 & 1 \\
\hline Yes & & & $2.43(1.30-4.52)^{* *}$ & $1.70(0.76-3.82)$ \\
\hline \multicolumn{5}{|l|}{ Presence of refuse in or around the house } \\
\hline No & & & 1 & 1 \\
\hline Yes & & & $0.57(0.29-1.09)$ & $0.83(0.35-1.97)$ \\
\hline
\end{tabular}

*Adjusted odds ratio

${ }^{* *} p<0.05$

and 95\% C.I. is 1.10-4.47). This finding corroborates studies in Jigjiga District, Somali Region [13]; in Mecha District, West Gojam Zone [6]; in rural areas of Shebedino District [28]; and in Medebay Zana District, northwest Tigray [29]. These studies indicate that mother/ guardian-child transmission of diarrhea may occur via contaminated food and water and mothers'/guardians' lack of awareness of these diarrhea risks.

The five critical times for handwashing with soap and water were before preparing food, before eating food, before feeding under-five child, after defecation, and after contact with feces of an under-five child [30]. 
Accordingly, mothers'/guardians' unhygienic handwashing practices after cleaning children is another exogenous factor for the child to acquire the disease. In this study, after adjusting for all predictors of childhood diarrhea, children of mothers/guardians who did not wash their hands using soap after contact with child feces were six times more likely to develop diarrheal disease than their counter parts. This finding is similar to reports from Arba-Minch District [27]; Sheko District in southwest Ethiopia [24]; Jigjiga District [13]; Banten Province, Indonesia [31]; and southwest Nigeria [32]. The possible explanation could be that mothers/guardians failing to wash their hands after contact with child feces are exposing their children to diarrheal pathogens.

Water may become unsafe at any point between collection and use. Clean water can easily become contaminated when dirty cups are used [33]. In the current study, after controlling for all confounders of under-five diarrhea, children of mothers or guardians who used dippers to draw water from the container were three times more likely to develop diarrheal disease than their counterparts who did not use dippers. The same relationship between the size of openings of water jars and diarrhea in children was reported in Cameroon [9] and Malaysia [34]. This could be explained by the introduction of pathogens into water stored especially in widemouthed jars through contaminated hands as well as dirty dippers. This finding was corroborated by a study in Zambia [35].

This study associated the presence of trash and flies with diarrhea, corroborating other studies [33]. After adjusting for all predictors of childhood diarrhea, underfive children from households that did not have a refuse disposal facility were two times more likely to develop diarrhea than children from households that had these facilities, which is consistent with studies in Nekemte Town, Western Ethiopia [7], and in Sheko District, Southwest Ethiopia [24]. This may be due to increased risk of disease transmission around refuse dumps.

\section{Strengths and limitations}

The current study had several strengths and limitations. Being a community-based type of study and the use of multiple documents to prepare the questionnaire are the strengths of this study. However, the use of crosssectional study design method is a limitation because causal inferences are very difficult to address. The time when the study was conducted could be another limitation of this study because the study was conducted in May, the driest and the hottest month of 2018. Therefore, future studies addressing all seasons of the year are encouraged. We collected information on diarrhea for the 2 weeks prior to the interview, which might have caused recall bias. However, this was minimized by asking mothers/caregivers repeatedly about the specific days when children had diarrhea. The other limitation was that data were collected by field workers and supervisors who are not paramedical staff. However, the field workers and supervisors were properly trained on data collection and supervision, respectively.

\section{Conclusion and recommendations}

Nearly one out of four children under the age of 5 years was found to have diarrhea. Despite efforts made by different stakeholder to alleviate the health problem related with childhood diarrhea, this public health problem needs further investigation to identify the possible predisposing factors and to plan and implement prevention strategies. Predisposing factors of maternal diarrhea, poor handwashing practices by the mothers/guardians after cleaning the children's bottoms, use of scoops for drawing water from the container, and absence of refuse disposal facilities were significantly associated with diarrhea.

Based on the findings of this study, the authors recommend educating mothers and guardians regarding the mode of transmission of diarrheal diseases and how to protect themselves and their under-five children including early treatment as preventive measures. The authors also recommend that mothers and guardians be trained in proper handwashing specifically after cleaning their children's bottom, safe storage, and handling of drinking water after bringing it from the source and on proper disposing of household wastes to minimize exposure to diarrheal pathogens among their children. In the long term, the situation may be improved by providing formal education above primary level to the rural population; specifically to mothers/caregivers to make them aware the risk and prevention of diarrhea.

\section{Abbreviations \\ AOR: Adjusted odds ratio; OR: Odds ratio; Cl: Confidence interval}

\section{Acknowledgements}

We would like to express our gratitude to the Ethiopian Institute of Water Resources, Addis Ababa University, for financial support. We like to extend our gratitude to study participants, data collectors, and supervisors. We are also grateful to the staff of the following: Dire Dawa Regional Health Bureau, Biyo Awale Health Center, Bishan Behe Health Post, Wahil Health Center, Melka Jebdu Health Center, and Hula Hulul Health Post for their kind support and helpfulness in the successful completion of data collection. National Research Ethics Review Committee is also appreciated for reviewing and approving the proposal.

\section{Authors' contributions}

ETS, SRG, and BM conceived the study, drafted the proposal, monitored data collection, and coordinated field work. ETS, SRG, and BM carried out data analysis and interpretation of the finding and wrote the manuscript. ETS, SRG, and BM contributed all necessary inputs for the study. HK edited the manuscript. All authors read and approved the final manuscript.

\section{Funding}

The principal author, a PhD student in Water and Public Health at Addis Ababa University, Ethiopian Institute of Water Resources, was funded by the University with ID No. GSR/0105/08. 


\section{Availability of data and materials}

Data on which the conclusions of the manuscript rely are summarized in texts and tables in this manuscript. Nevertheless, if need be the main data in machine readable format can be obtained from the principal author (ETS) using formal ways of communication.

\section{Ethics approval and consent to participate}

Ethical clearance was obtained from National Research Ethics Review Committee (NRERC) of Ethiopia, Addis Ababa. Letter was written to Dire Dawa Regional Health Bureau by the Ethiopian Institute of Water Resources; the Bureau in turn wrote a support letter to Wahil Health Center, Biyo Awale Health Center, Bishan Behe Health Post, Melka Jebdu Health Center and Hula Hulul Health Post to get their permission and for their possible cooperation. Information about the study and its objective was provided to mothers and guardians and written consent was obtained. Data gathered from the study participants was used only for the purpose of this study and results were kept confidential. Data collectors advised mothers and guardians to seek care for diarrhea of their children at nearby health posts or health centers.

\section{Consent for publication}

This manuscript did not include data from others research work

\section{Competing interests}

The authors announce that they have no competing interests.

\section{Author details}

'Ethiopian Institute of Water Resources, Addis Ababa University, Addis Ababa, Ethiopia. ${ }^{2}$ College of Health and Medical Sciences, Haramaya University, Harar, Ethiopia. ${ }^{3}$ San Francisco Medical Center, University of California, San Francisco, CA, USA.

Received: 23 April 2020 Accepted: 28 July 2020

Published online: 06 August 2020

\section{References}

1. Keusch GT, Walker CF, Das JK, Horton S, Habte D. Diarrheal diseases. In: Black RE, Laxminarayan R, Temmerman M, Walker N, editors. Reproductive maternal newborn and child health. Disease control priorities. Volume 2. Washington, DC: The World Bank; 2016. p. 163-85.

2. MacGill, M., What you should know about diarrhea. Available at https:// www.medicalnewstoday.com/articles/158634.php. Accessed 7 August 2019. 2017.

3. World Health Organization, Diarrhoeal disease fact sheet. №330 May 2017. 2017.

4. Danquah L, Mensah CM, Agyemang S, Awuah E. Risk factors associated with diarrhea morbidity among children younger than five years in the Atwima Nwabiagya District, Ghana: a cross-sectional study. Sci J Public Health. 2015; 3(3):344-52.

5. Bado AR, Susuman AS, Nebie El. Trends and risk factors for childhood diarrhea in sub-Saharan countries (1990-2013): assessing the neighborhood inequalities. Glob Health Action. 2016;9(1):30166 https://www.tandfonline. com/doi/full/10.3402/gha.v9.30166.

6. Desalegn M, Kumie A, Tefera W. Predictors of under-five childhood diarrhea: Mecha District, West Gojjam, Ethiopia. Ethiop J Health Dev. 2011;25(3):192200.

7. Regassa G, Birke W, Deboch B, Belachew T. Environmental determinants of diarrhea among under-five children in Nekemte Town, western Ethiopia. Ethiop J Health Sci. 2008;18(2). https://www.ajol.info/index.php/ejhs/article/ viewFile/145957/135474

8. Kalakheti B, Panthee K, Jain KC. Risk factors of diarrhea in children under five years in urban slums. J Lumbini Med Coll. 2016;4(2):94-8.

9. Tambe A, Nzefa L, Nicoline N. Childhood diarrhea determinants in subSaharan Africa: a cross sectional study of Tiko-Cameroon. Challenges. 2015; 6(2):229-43.

10. World Health Organization, CHERG-WHO methods and data sources for child causes of death 2000-2012. Global Health Estimates Technical Paper. WHO/HIS/HSI/GHE 2014

11. Central Statistical Agency (CSA) [Ethiopia] and ICF International, Ethiopia demographic and health survey 2016. Addis Ababa, Ethiopia, and Rockville, Maryland, USA: CSA and ICF. 2016.
12. Getachew A, Guadu T, Tadie A, Gizaw Z, Gebrehiwot M, et al. Diarrhea prevalence and sociodemographic factors among under-five children in rural areas of North Gondar Zone, Northwest Ethiopia. Int J Pediatr. 2018; 2018. https://doi.org/10.1155/2018/6031594.

13. Hashi A, Kumie A, Gasana J. Prevalence of diarrhoea and associated factors among under-five children in Jigjiga District, Somali Region, Eastern Ethiopia. Open J Prev Med. 2016;6(10):233-46.

14. Mengistie B, Berhane $Y$, Worku A. Prevalence of diarrhea and associated risk factors among children under-five years of age in Eastern Ethiopia: a crosssectional study. Open J Prev Med. 2013;3(07):446. https://doi.org/10.4236/ ojpm.2013.37060.

15. Alebel A, Tesema C, Temesgen B, Gebrie A, Petrucka P, et al. Prevalence and determinants of diarrhea among under-five children in Ethiopia: a systematic review and meta-analysis. PLoS One. 2018;13(6):e0199684. https://doi.org/10.1371/journal.pone.0199684.

16. Dejene, K., B. Nagga, and A. Tadesse, Prevalence and associated factors of diarrhea morbidity among-under five children in rural kebeles of Dire Dawa Administration, Ethiopia (Master's Thesis), 2016 Harmaya University.

17. Mekonnen M, Geda B, Teklemariam Z, Weldegebreal F, Balakrishnan S. Prevalence of childhood diarrhea and associated risk factors in Dire Dawa, eastern Ethiopia. J Public Health. 2018:26(1):29-37.

18. Van Belle G, Fisher LD, Heagerty PJ, Lumley T. Biostatistics: a methodology for the health sciences. Vol. 519: Wiley; 2004.

19. Vierron E, Giraudeau B. Design effect in multicenter studies: gain or loss of power? BMC Med Res Methodol. 2009;9(1):39. https://doi.org/10.1186/14712288-9-39.

20. Anteneh ZA, Andargie K, Tarekegn M. Prevalence and determinants of acute diarrhea among children younger than five years old in Jabithennan District, Northwest Ethiopia, 2014. BMC Public Health. 2017;17(1):99 https:// bmcpublichealth.biomedcentral.com/articles/10.1186/s12889-017-4021-5.

21. El Gilany A, Hammad S. Epidemiology of diarrhoeal diseases among children under age 5 years in Dakahlia, Egypt. E Mediterr Health J. 2005;11: 762-75

22. Mihrete TS, Alemie GA, Teferra AS. Determinants of childhood diarrhea among underfive children in Benishangul Gumuz Regional State, North West Ethiopia. BMC Pediatr. 2014;14(1):102 https://bmcpediatr. biomedcentral.com/articles/10.1186/1471-2431-14-102.

23. Godana W, Mengiste B. Environmental factors associated with acute diarrhea among children under five years of age in derashe district, Southern Ethiopia. Sci J Public Health. 2013;1(3):119-24.

24. Gebru T, Taha M, Kassahun W. Risk factors of diarrhoeal disease in underfive children among health extension model and non-model families in Sheko district rural community, Southwest Ethiopia: comparative crosssectional study. BMC Public Health. 2014;14(1):1 http://www.biomedcentral. com/1471-2458/14/395.

25. Boadi $\mathrm{KO}$, Kuitunen M. Childhood diarrheal morbidity in the Accra Metropolitan Area, Ghana: socio-economic, environmental and behavioral risk determinants. J Health Popul Deve Countries. 2005;7(1):15-22.

26. Gedamu G, Kumie A, Haftu D. Magnitude and associated factors of diarrhea among under five children in Farta wereda, North West Ethiopia. Qual Prim Care. 2017;25(4):199-207.

27. Mohammed S, Tilahun M, Tamiru D. Morbidity and associated factors of diarrheal diseases among under five children in Arba-Minch district, Southern Ethiopia, 2012. Sci J Public Health. 2013;1(2):102-6.

28. Tamiso A, Yitayal M, Awoke A. Prevalence and determinants of childhood diarrhoea among graduated households, in rural area of Shebedino district, Southern Ethiopia, 2013. Science. 2014:2(3):243-51.

29. Asfaha KF, Tesfamichael FA, Fisseha GK, Misgina KH, Weldu MG, et al. Determinants of childhood diarrhea in Medebay Zana District, Northwest Tigray, Ethiopia: a community based unmatched case-control study. BMC Pediatr. 2018;18(1):120 https://bmcpediatr.biomedcentral.com/articles/10.11 86/s12887-018-1098-7.

30. Center for Disease Control and Prevention, Handwashing: clean hands save lives. Centers for Disease Control and Prevention, Atlanta, 2013: p. available at: https://www.cdc.gov/handwashing/index.html. Accessed 17 June 2017.

31. Rohmawati N, Panza A, Lertmaharit O. Factors associated with diarrhea among children under five years of age in Banten province. Indonesia J Health Res. 2012:26(1):31-4.

32. Aluko OO, Afolabi OT, Olaoye EA, Adebayo AD, Oyetola SO, et al. The management of the faeces passed by under five children: an exploratory, cross-sectional research in an urban community in Southwest Nigeria. BMC 
Public Health. 2017;17(1):178 https://bmcpublichealth.biomedcentral.com/ articles/10.1186/s12889-017-4078-1.

33. AHRTAG, Dialogue on diarrhea: health basics: water and sanitation. Available at: http://www.rehydrate.org/dd/su31.htm. Accessed 21 August 2019. 1987.

34. Knight SM, Toodayan W, Caique WC, Kyi W, Barnes A, et al. Risk factors for the transmission of diarrhoea in children: a case-control study in rural Malaysia. Int J Epidemiol. 1992;21(4):812-8.

35. Quick RE, Kimura A, Thevos A, Tembo M, Shamputa I, et al. Diarrhea prevention through household-level water disinfection and safe storage in Zambia. Am J Trop Med Hyg. 2002;66(5):584-9.

\section{Publisher's Note}

Springer Nature remains neutral with regard to jurisdictional claims in published maps and institutional affiliations.

Ready to submit your research? Choose BMC and benefit from:

- fast, convenient online submission

- thorough peer review by experienced researchers in your field

- rapid publication on acceptance

- support for research data, including large and complex data types

- gold Open Access which fosters wider collaboration and increased citations

- maximum visibility for your research: over $100 \mathrm{M}$ website views per year

At BMC, research is always in progress.

Learn more biomedcentral.com/submissions 